\title{
Pengaruh Penggunaan Handphone di Kalangan Remaja Katolik Terhadap Komunikasi Keluarga di Stasi Santo Paulus Seberaya Paroki Santa Perawan Maria Diangkat Ke Surga Kabanjahe
}

\author{
Yohanes Sukendar ${ }^{1}$ | sukendar@stp-ipi.ac.id \\ Alni Vera Br. Depari² $\mid$ alnivbd@ @student.stp-ipi.ac.id \\ Sekolah Tinggi Pastoral Yayasan Institut Pastoral Indonesia Malang: Jln. Seruni No. 6 Malang 65141 \\ Jawa Timur - Indonesia \\ Abstract \\ This paper investigates whether or not the influence of mobile phone use among Catholic youth \\ on family communication. Is there any influence on mobile phone use among Catholic teenagers \\ in their communication with their parents or family members? Whether the communication of \\ teenagers with members becomes increasingly locked up by using mobile phones or has no \\ influence at all, it means that the teenagers still communicate well even if they use a mobile phone. \\ The study involved 31 Catholic teenagers in one of the stasi in Kabanjahe Parish, North Sumatera. \\ The analysis of the research's results was conducted statistically with the Y regression significance \\ test against $X$ and correlation test. Hypothesis testing with a value of -17.19 exceeds the $F$ table \\ value of 4.18 which means there is an influence of mobile phones on negative communication: the \\ higher the use of mobile phones and the ability of users, the lower the communication with family \\ members. Correlation calculation of -0.433 states that there is an inverse (negative) relationship \\ which means the higher the use of mobile phones the lower the communication with family \\ members and the lower the time of mobile phone use the higher the communication with the family.
}

Keywords: catholic teenagers, family communication, handphone, influence.

Abstrak

Tulisan ini bermaksud menyelidiki ada tidaknya pengaruh penggunaan handphone di kalangan remaja Katolik terhadap komunikasi keluarga. Apakah ada pengaruh penggunaan handphone di kalangan remaja Katolik dalam komunikasinya terhadap orang tua atau anggota keluarganya. Apakah komunikasi remaja dengan anggota menjadi semakin berkurung dengan menggunakan handphone ataukah tidak ada pengaruh sama sekali, artinya para remaja tetap berkomunikasi dengan baik biarpun ia menggunakan handphone. Penelitian ini merupakan penelitian populasi yang melibatkan 31 remaja Katolik di salah satu stasi di Paroki Kabanjahe Sutamera Utara. Analisa hasil penelitian dilakukan secara statistik dengan uji signifikansi regresi Y terhadap X dan uji korelasi. Pengujian hipotesis dengan nilai -17,19 melebihi nilai $\mathrm{F}$ tabel sebesar 4,18 yang berarti ada pengaruh handphone terhadap komunikasi yang bersifat negatif: semakin tinggi penggunaan handphone dan kemampuan pengguna maka semakin rendah berkomunikasi dengan anggota keluarga. Penghitungan korelasi sebesar -0,433 menyatakan ada hubungan yang bersifat terbalik (negatif) yang berarti semakin tinggi penggunaan handphone semakin rendah berkomunikasi dengan anggota keluarga dan semakin rendah waktu penggunaan handphone semakin tinggi berkomunikasi dengan keluarga

Kata Kunci: handphone, komunikasi keluarga, pengaruh, remaja katolik

\section{Latar Belakang}

Manusia dalam menjalankan aktivitas kesehariannya tidak terlepas dari bantuan teknologi. Menurut Tibertius Catur dalam bukunya literali Teknologi dan keutuhan ciptakan mengatakan: Teknologi sebagai alat atau sistem yang menyederhanakan kehidupan manusia, membantu memberikan kemudahan di segala bidang, inilah alasannya kenapa manusia begitu tergantung pada teknologi. Teknologi bermacammacam seperti teknologi informasi dan komunikasi, dan sebagainya (Catur cs, 2019,3). Komunikasi sebagai satu proses yang dinamis, selalu berubah dan tidak pernah selesai (B. Lukas, 2003, 16). Suatu proses komunikasi dapat dikatakan efektif/berhasil bilamana diantara penyebar pesan dan penerima pesan terdapat satu pengertian yang sama mengenai isi pesan. (Sastro Putranto, 1987,7) 
Perkembangan Media Komunikasi sekitar tahun 1960-1970-an, media komunikasi yang disebut oleh Paus adalah Film, radio, dan televisi. Kemudian, sekitar tahun 1980-1990an, muncul telepon yang semakin meningkatkan komunikasi antarpribadi yang sangat cepat tanpa batas waktu dan ruang. Setelah tahun 2000an, perkembangan media komunikasi yang sangat berperan bagi kehidupan adalah Internet KWI, 2015, 38). Perkembangan alat komunikasi ini menjadi hal yang tidak lagi mengherankan dimana komunikasi menjadi sangat cepat dan instan. Untuk berkomunikasi satu dengan yang lain, tidak lagi harus bertemu secara langsung. Alat komunikasi canggih yang sering disebut handphone mempengaruhi perilaku dan cara berkomunikasi pada zaman ini.

Handphone memiliki berbagai aplikasi yang dapat menjadi sarana edukatif,komunikasi,hiburan. Handphone juga menjadi sangat efektif untuk dibawa sehingga menyebabkan banyak orang terbantu dengan adanya perkembangan media komunikasi tersebut. Handphone yang dulunya merupakan sebuah kebutuhan tersier kini menjadi kebutuhan primer bagi anak yang hidup di zaman milineal. Apabila tidak membawa handphone, akan merasa ada yang kurang ataupun ketinggalan. Di kalangan anak-anak dan kaum muda, media komunikasi sangat berpengaruh sebab mereka adalah penerima pertama dan langsung dari media. Mereka adalah kelompok yang paling terkena arus informasi dan gambar yang dihasilkan oleh media komunikasi (MKS 19) (KWI, 2015, 45). Tidak dapat dipungkiri bahwa mereka memiliki cara berkomunikasi yang sangat jauh berbeda apabila dibandingkan dengan zaman-zaman sebelumnya. Handphone seringkali mengendalikan kegiatan komunikasi para anak remaja. Anak yang tidak mampu menerima perkembangan handphone dengan baik akan lebih senang untuk berkomunikasi dengan teman sebayanya melalui media handphone dibanding berkomunikasi dengan orangtua atau saudaranya sendiri.

\section{Literatur Review}

Menurut McLuhan dalam Morissan, teknologi komunikasi menjadi penyebab utama perubahan budaya. Kehidupan keluarga, lingkungan kerja, sekolah, pertemanan, kegiatan keagamaan, politik, dan sebagainya semua terpengaruh teknologi komunikasi. Interaksi manusia dengan manusia telah digantikan menjadi interaksi manusia dan seringkali tidak disadari teknologi dapat mengurangi interaksi seseorang secara langsung dengan orang-orang terdekat yang ada di sekitar (misalnya antara orang tua dan anak di rumah masing-masing sibuk dengan handphone-nya). Di lain pihak, Remaja merupakan kelompok manusia yang penuh potensi yang perlu untuk dimanfaatkan. Secara psikologis, usia remaja adalah usia di mana individu berintegrasi dengan masyarakat dewasa, usia di mana anak tidak lagi merasa di bawah tingkat orang-orang yang lebih tua melainkan berada dalam tingkat yang sama (Aziz Muchlitz dan Nurainah, 2019,22). Hal ini tentu menjadi suatu faktor yang menyebabkan bagaimana remaja merasa bahwa ia sudah pantas untuk mengoperasikan handphone yang ia miliki. Remaja juga cenderung lebih menyukai berkomunikasi dengan teman sebayanya yang dapat ia jumpai melalui handphone dibanding dengan berkomunikasi dengan orang disekitanya.

Handphone menjadi salah satu sarana komunikasi antar anggota keluarga yang hidup saling berjauhan, juga bermanfaat sebagai sumber belajar anak, sarana jejaring sosial, sarana hiburan untuk semua anggota keluarga (Aziz Muchlitz dan Nurainah, 2019, 113). Melalui handphone, jarak yang jauh dapat dijangkau dengan membangun komunikasi dunia maya, mempercepat komunikasi, serta dapat berkomunikasi juga melalui grup-grup di berbagai jenis aplikasi Handphone. Bagi orangtua sendiri dapat memantau,menanyakan keadaan anaknya, membantu proses edukatif anak melalui handphone tersebut.

Kemajuan media komunikasi digital tidak saja membawa dampak positif bagi keluarga melainkan pada era digital ini media komunikasi yang berkembang pesat justru menimbulkan persoalan, teristimewa persoalan relasi dalam keluarga. Kebersamaan dan keutuhan keluarga sering terganggu oleh kehadiran handphone. Jika orang tidak dapat mengendalikan dirinya dalam menggunakan media digital, seringkali membuatnya tenggelam dalam suasana bersosial media sehingga melupakan waktu untuk 
berinteraksi dalam keluarga, bahkan menghiraukan lingkungan terdekatnya (Aziz Muchlitz dan Nurainah, 2019, 113).

Pengaruh handphone antara orangtua dan anak juga tidak dapat dihindari. Sebagai pendidik, bapakibu sering menghadapi tantangan berat di era digital. Kemudahan virtual menyuguhkan kemudahan dan sekaligus tantangan bagi kehidupan orang-orang dewasa ini. Kemudahan dan tantangan ini disuguhkan bukan hanya bagi hidup "duniawi”, tetapi juga bagi hidup beriman (Aziz Muchlitz dan Nurainah, 2019, 113).

Gereja Katolik bersifat terbuka akan kemajuan teknologi yang selalu membawa dampak bagi banyak orang dalam skala yang cukup besar. Salah satunya perkembangan Media Komunikasi terkhusus Handphone merupakan suatu hal yang tidak bisa dihindari dan akan selalu bersifat dinamis. Dunia yang sangat mudah mendekatkan yang jauh tentunya membuat perubahan secara makro. Banyak sekali masyarakat menggunakan perkembangan Handphone ini untuk mencari celah agar komunikasi yang diinginkan mencapai tujuannya. Melalui Handphone, dunia yang begitu luas dapat disempitkan dimana penyampaian pesan, mencari berita, hiburan, belanja, dan sebagainya menjadi sangat instan. Tidak perlu lagi mengirim surat dalam waktu yang lama sehingga memudahkan masyarakat dalam saling bertukar informasi. Selain itu, penggunaan handphone untuk memenuhi kebutuhan pangan, sandang, edukatif dapat dilakukan secara online pada zaman ini.

Keluarga sebagai persekutuan terkecil, membutuhkan komunikasi antar anggota keluarganya. Komunikasi Keluarga sangat dibutuhkan untuk menjaga keutuhan, keharmonisan dan kebersamaan anggota keluarga yang akan membawa keluarga saling menyapa, saling mengenal dan saling mengerti satu sama lain. Kecanggihan media komunikasi digital di tengah-tengah keluarga tentunya memiliki peluang yang besar untuk semakin mendekatkan satu sama lain. Orangtua saat berjauhan dengan anaknya, dengan mudah memantau keadaan dari anaknya tanpa harus menunggu waktu yang lama untuk saling berhubungan.

Keluarga-keluarga sebaiknya memanfaatkan media digital bukan sekedar untuk mengembangakn hobi berjejaring atau untuk mendapatkan hiburan-hiburan, tetapi justru seharusnya mengembangkan keluarga sebagai komunitas cinta dan iman. Oleh karena itu, setiap keluarga pada era ini jangan sampai diperbudak oleh media digital. Bagaimana pun, media digital tetaplah sarana untuk satu tujuan yang lebih luhur yaitu unitif, partisipatif, edukatif dan tansformatif (KWI, 2015, 177).

Satu hal yang sering dilupakan dalam mencari rahasia kebahagiaan rumah tangga ialah peranan komunikasi dalam rumah tangga. Secara umum, fenomena komunikasi memiliki relevan yang amat kuat bagi berlangsung dan lestarinya sistem kehidupan sosial. Tanpa komunikasi, maka kebekuan, kemandegan dan bahkan kematian proses kehidupan manusia tidak mungkin dapat dihindarkan. Demikian juga halnya dalam hubungan rumah tangga. Komunikasi sangat penting untuk hubungan daIam keluarga, seb ab tanpa komunikasi, hubungan-hubungan yang akrab tidak dapat dijalin atau tetap hidup. Banyak problem yang timbul dan berakar kepada masalah komunikasi rumah tangga (Kuntaraf Katheleen dan Kuntaraf Johathan, 1999, 1). Setiap orang pasti memiliki kerinduan untuk memiliki rumah tangga yang damai, bahagia, sejahtera. Rumah tangga akan menjadi bahagia akan diperoleh melalui komunikasi yang baik. Namun, komunikasi yang baik hanya boleh terjadi dengan kuasa Allah (Kuntaraf Katheleen dan Kuntaraf Johathan, 1999, 30). Komunikasi seringkali menjadi terhambat akibat dari penyalahgunaan handphone. Komunikasi secara verbal yang sangat dibutuhkan untuk dapat mencurahkan rasa cinta kini mulai ditenggelamkan arus komunikasi digital.

Dalam 1 Yohanes 1:3, menunjukkan bagaimana seharusnya hubungan antara anggota-anggota rumah tangga. Untuk mendapatkan keluarga yang harmonis tentu membutuhkan komunikasi yang baik. Dimana suami-istri saling menghargai satu sama lain dan antara orangtua kepada anak memberi asuhan dan didikan kepada anak mereka. Sang anak juga harus taat dan turut atas nasehat yang diberikan oleh orangtuanya. Dalam proses untuk mencapai hubungan keluarga yang harmonis tentu membutuhkan komunikasi yang sehat untuk saling mengenal dan menghargai dalam persekutuan intim keuarga. 
Yang menjadi rumusan masalah dalam penelitian ini adalah Apakah ada pengaruh yang signifikan antara penggunaan handphone terhadap komunikasi remaja Katolik dengan keluarganya di Stasi Santo Paulus Seberaya? Dengan rumusan masalah tersebut maka tujuan dari penelitian ini adalah untuk menemukan ada tidaknya pengaruh penggunaan handphone di kalangan remaja dterhadap komunikasinya dengan anggota keluarga.

\section{Metodologi}

Penelitian ini adalah penelitian kuantitatif yang meneliti populasi atau sampel tertentu. Pengumpulan data menggunakan instrumen penelitian, analisis data bersifat kuantitatif/statistik, dengan tujuan untuk menggambarkan dan menguji hipotesis yang telah ditetapkan (Sugiono, 2018 15). Dalam penelitian ini ada dua variabel yaitu variabel bebas dan variabel terikat. Yang menjadi variabel bebas dalam penelitian ini adalah pengaruh penggunaan handphone, sedangkan variabel terikatnya adalah komunikasi dalam keluarga.

Ada tiga sub variabel yang berkaiatan dengan penggunaan handphone yaitu, kualitas handphone, kemampuan pengguna dan waktu penggunaan. Sedangkan sub varibael untuk komunikasi dalam keluarga meliputi komunikasi remaja dengan orang tuanya dan komuniasi remaja dengan saudaranya (adik atau kakak)

Yang menjadi populasi penelitian ini adalah remaja Katolik dengan pembatasan sebagai berikut: Remaja yang beragama Katolik yang berumur 12-21 Tahun; Remaja Katolik yang memiliki handphone Android atau IOS; Remaja Katolik yang memiliki Orangtua lengkap yaitu Ayah dan Ibu; Remaja Katolik yang memiliki Saudara atau saudari; Orangtua Remaja Katolik yang memiliki handphone Android atau IOS

Penelitian ini adalah penelitian populasi, semua remaja yang memenuhi syarat di atas, yang berjumlah 31 orang. Penelitian ini dilaksanakan di sebuah stasi yaitu Stasi Santo Paulus Seberaya, Paroki Maria Diangkat ke Surga Kabanjahe, Keuskupan Agung Medan, Sumatera Utara.

Pengumpulan data dilaksanakan dengan menggunakan angket tertutup dengan skala Likert. Untuk setiap instrumen/petrtanyaan diberi lima pilihan jawaban. Sedangkan untuk pengolahan data digunakan tes statistik regresi sederhana.

\section{Hasil dan Pembahasan}

Ada beberapa temuan yang menarik dalam penelitian ini, antara lain: Pertama tentang kemampuan remaja dalam menggunakan handphone. Kemampuan Pengguna handphone. Remaja Katolik dalam menggunakan handphone Sangat baik. Hal ini dibuktikan dengan skor rata-rata 4,6 yang berarti mereka sangat mampu dan menguasai berbagai aplikasi yang ada di handphone mereka.

Kedua berdasarkan perhitungan melalui pengolahan data dengan skor, diperoleh skor rata- rata bahwa Remaja Katolik kurang baik dalam hal komunikasi keluarga yang dibuktikan dengan perolehan skor 2,06 yang berarti tingkat komunikasi remaja dengan anggota keluarga kurang.

\section{Kesimpulan}

Dari hasil analisis data dengan menggunakan regresi tentang Pengaruh Penggunaan Handphone untuk kalangan Remaja Katolik terhadap Komunikasi Keluarga dengan Uji signifikansi Regresi Y terhadap $\mathrm{X}$ dengan hipotesis dengan nilai -17,19 menunjukkan lebih besar daripada $\mathrm{F}$ tabl sebesar 4,18 jadi ada Pengaruh Handphone terhadap komunikasi yang bersifat negatif yang berarti semakin tinggi penggunaan Handphone dan kemampuan pengguna maka semakin rendah berkomunikasi dengan anggota keluarga.

Penemuan di atas didukung dengan pengolahan data menggunakan korelasi diperoleh -0,433 ada hubungan korelasi yang bersifat terbalik (negatif) yang berarti semakin tinggi penggunaan Handphone semakin rendah berkomunikasi dengan anggota keluarga dan semakin rendah waktu penggunaan 
handphone semakin tinggi berkomunikasi dengan keluarga.

Sebuah saran bagi orang tua dan para pendidik untuk membimbing para remaja supaya handphone digunakan untuk hal-hal yang positif. Perlu bimbingan supaya remaja semakin mamu menggunakan handphone untuk berkomunikasi dengan leluarga di samping tetap perlu berkomunikasi denhan face to face.

\section{Ucapan Terima Kasih}

Terima kasih disampaikan kepada setiap pihak yang terlibat dalam penelitian ini, yang namanya tidak dapat disebutkan satu persatu, terutama kepada Ketua dan Umat Stasi Santo Paulus Seberaya, Paroki Maria Diangkat ke Surga Kabanjahe, Keuskupan Agung Medan yang telah mendukung dilaksanakannya penelitian ini.

\section{Daftar Rujukan}

Aziz Muchliz dan Nurainiah. Pengaruh Penggunaan Handphone terhadap Interaksi Sosial Remaja di Desa Dayah Meunara Kecamatan Kutamakmur Kabupaten Aceh Utara. P. 22 (Diakses Online pada 4 Mei 2019)

B. Lukas \& Hermawan, Fransisca., Budaya Media (Flores:Nusa Indah, Cetakan 1,2003

Catur, Tiburtius \& Catur, Stefanus \& Sutarto, Sentot., ModuI APP Umum 2019 Itterasi TeknoIogi dan keutuhan ciptaan (MaIang:Dioma,cetakan pertama,2019)

Darmadi Hamid. 2013. Metode Penelitian Pendidikan dan Sosial , (Bandung: Alfabeta,Cv

Kuntaraf- KathIeen Iiwidjaja \& Kuntaraf Jonathan. 1999. Komunikasi KeIuarga Kunci Kebahagiaan Anda (Manullang F. Jahotner, Ed), (Bandung: Indonesia Publishing House

KWI. Hidup di Era DigitaI (Yogyakarta:Kanisius, Cetakan pertama,2015) p.38

Sugiyono, Metode Penelitian Pendidikan: Pendekatan Kuantitatif, Kualitatif dan $R \& D$, (Bandung: Alfabeta CV, Cetakan ke 27 April 2018) 